\title{
Physiological and Growth Responses of St. Augustinegrass Cultivars to Salinity
}

\author{
A.E. Dudeck ${ }^{1}$, C.H. Peacock ${ }^{2}$, and J.C. Wildmon ${ }^{3}$ \\ Environmental Horticulture Department, University of Florida, Gainesville, \\ FL 32611 \\ Additional index words. 'Floralawn', 'Floratam', 'Floratine', leaf osmotic potential, leaf \\ turgor potential, leaf water potential, salt tolerance, 'Seville', Stenotaphrum secundutum, \\ thermocouple psychrometer, turfgrass
}

\begin{abstract}
Salt tolerance in grasses is needed due to increased restrictions on limited fresh water resources and to saltwater intrusion into groundwater. St. Augustinegrass [Stenotaphrum secundatum (Walt.) Kuntze] is used widely as a lawngrass in states bordering the Gulf of Mexico. We describe the response of four St. Augustinegrass cultivars to solution cultures differentially salinized with synthetic seawater. A sea salt mixture was added to half-strength Hoagland's No. 2 nutrient solution to provide six salinity treatments ranging from 1.1 to $41.5 \mathrm{dS} \cdot \mathrm{m}^{-1}$. Adjustments in leaf water potential, leaf osmotic potential, and leaf turgor potential were measured as salt levels were increased gradually at 2-day intervals over 10 days. Salinity effects on growth of top, crown, and root of each cultivar were measured over 3 months. Turfgrasses differed in their response, but were consistent in adjustment in leaf water potential and in leaf turgor potential as salinity increased. Leaf water potential, leaf osmotic potential, and leaf turgor potential decreased linearly with increased salinity, but a positive turgor of $0.1 \mathrm{MPa}$ was maintained at a salt concentration equal to that of seawater. 'Seville', the most salt-tolerant St. Augustinegrass cultivar, exhibited a $50 \%$ reduction in top growth at $28.1 \mathrm{dS} \cdot \mathrm{m}^{-1}$, while 'Floratam', 'Floratine', and 'Floralawn' St. Augustinegrasses showed the same reduction in top growth at $22.8 \mathbf{~ d S} \cdot \mathbf{m}^{-1}$. Differences between cultivars were greatest at salinity levels $<10 \mathrm{dS} \cdot \mathrm{m}^{-1}$, where 'Seville' was twice as salt-tolerant compared to other cultivars. The grasses did not die, although top growth of all cultivars was severely reduced at a salt level equal to seawater.
\end{abstract}

Increased salt tolerance in grasses is needed because of salt accumulation in soil (Hoos, 1981), increased restrictions on use of groundwater, and saltwater intrusion into groundwater (Parker, 1975). Turfgrass species and cultivars differ in their response to salinity (Dudeck and Peacock, 1985; Dudeck et al., 1983; Harivandi et al., 1982; Horst and Beadle, 1984; Horst and Taylor, 1983; Lunt et al., 1961; Youngner et al., 1967). Physiological responses to salinity include growth suppression, lowered osmotic potential, and/or a loss of turgor potential (Levitt, 1980; Peacock and Dudeck, 1985). St. Augustinegrass is the most widely used lawngrass in Florida and is used extensively in other states bordering the Gulf of Mexico. St. Augustinegrass is reported to be salt-tolerant (Beard, 1973), but we found no documentation in the scientific literature. We conducted this investigation to compare

Received for publication 26 Nov. 1991. Accepted for publication 12 Aug. 1992. Florida Agricultural Experiment Station Journal Series no. R-01897. We acknowledge financial support in part from the Florida Turfgrass Association. The cost of publishing this paper was defrayed in part by the payment of page charges. Under postal regulations, this paper therefore must be hereby marked advertisement solely to indicate this fact.

${ }^{1}$ Professor of Turfgrass Science.

${ }^{2}$ Associate Professor of Crop Science, Turf. Present address: Dept. of Crop Science, North Carolina State Univ., Raleigh, NC 27695.

${ }^{3}$ Former Graduate Research Assistant. Present address: Lake City Community College, Lake City, FL 32055 . formulated with deionized water (Hoagland and Arnon, 1950). This volume allowed the bottom of each pot to extend $3.5 \mathrm{~cm}$ into the solution. Top growth $5 \mathrm{~cm}$ above the gravel was removed weekly.

All grasses were considered established by 24 June, rated visually for color and density, and blocked uniformly within five replications. All were of acceptable quality. A salt mixture was formulated to approximate the average individual salt composition of seawater (Svedrup et al., 1959). It contained (mg/kg dry salt) $788 \mathrm{NaCl}, 94 \mathrm{MgSO}_{4}, 73 \mathrm{MgCl}_{2}, 32 \mathrm{CaCl}_{2}$, $7 \mathrm{KHCO}_{3}$, and $6 \mathrm{KCl}$. This salt mixture was added at $0,6.4,12.8,19.2,25.6$, or 32.0 $\mathrm{g} \cdot \mathrm{liter}^{-1}$ to nutrient solution to give six average electrical conductivity (EC at 25C) levels of $1.1,10.3,18.8,26.9,34.5$, or $41.5 \mathrm{dS} \cdot \mathrm{m}^{-1}$, respectively. Electrical conductivities were recorded just before and after weekly solution changes. To minimize osmotic shock to the plants, salt concentration was increased in increments of $6.4 \mathrm{~g} \cdot$ liter $^{-1}$ at 2-dry intervals over 10 days, or until final treatment levels were reached.

Just before each salt increase, two most recently, fully expanded leaves from each cultivar were removed and their water potential was determined using chamber psychrometers calibrated with a series of $\mathrm{NaCl}$ solutions of known molality (Peacock and Dudeck, 1984). Leaves were then frozen to disrupt cell membranes and their osmotic potential was determined after freezing and thawing within the same psychrometer. By 5 July 1983, all salinity treatments were stabilized at their respective maximum levels.

Roots extraneous to the pot were removed monthly for 3 months. Top growth extending beyond the circumference of the pot was removed biweekly in a vertical plane along with leaf tissue $5 \mathrm{~cm}$ above the gravel. Tissue was dried in preweighed aluminum envelopes at $60 \mathrm{C}$ for $48 \mathrm{~h}$ to determine dry weights. Rate of top growth was based on the total of six biweekly harvests. At the end of the experiment, root tissue within pots was separated from crown tissue and both were dried as described by Dudeck and Peacock (1985). Crown tissue was defined as stems and leaves below the 5$\mathrm{cm}$ clipping height. Dry crown and root tissues were weighed, ashed at $450 \mathrm{C}$ for $12 \mathrm{~h}$, reweighed, and the difference was taken as total crown or root weight to eliminate errors caused by small gravel and/or sand clinging to the tissue.

The design was a split plot with five replications in which salinity was the main plot

Table 1. Signficance levels for salinity effects on leaf water potential components and growth of St. Augustinegrass cultivars as influenced by electrical conductivity (EC) of the solution culture.

\begin{tabular}{|c|c|c|c|c|c|c|c|}
\hline \multirow[b]{2}{*}{ Source } & \multirow[b]{2}{*}{ df } & \multicolumn{3}{|c|}{ Leaf potential } & \multicolumn{3}{|c|}{ Dry wt } \\
\hline & & Water & Osmotic & Turgor & Top & Crown & Root \\
\hline Block & 4 & $*$ & NS & $* *$ & $* * *$ & $* * *$ & NS \\
\hline $\mathrm{EC}$ & 5 & $* * *$ & $* * *$ & $* * *$ & $* * *$ & $* * *$ & $* * *$ \\
\hline Error A & 20 & & & & & & \\
\hline Cultivar (C) & 3 & * & NS & $* *$ & $* * *$ & $* * *$ & $* * *$ \\
\hline $\mathrm{C} \times \mathrm{EC}$ & 15 & NS & NS & NS & $* * *$ & NS & $* * *$ \\
\hline Error B & 72 & & & & . & & \\
\hline
\end{tabular}

ss, ,**,***Nonsignificant or significant at $P=0.05,0.01,0.001$, respectively. 

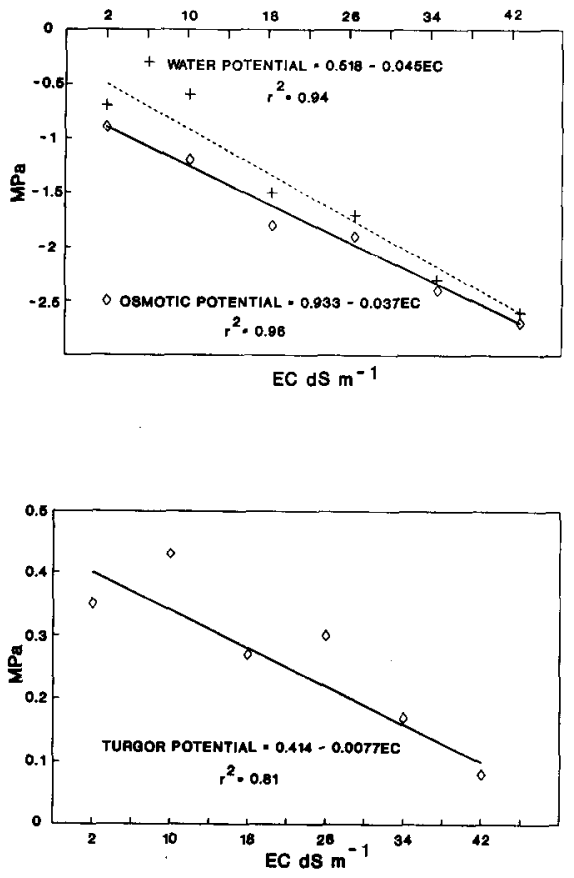

Fig. 1. Composite response in leaf water potentials of St. Augustinegrass cultivars to salinity. Each data point represents the mean of 20 observations.

effect and cultivar was the subplot effect. All data were subjected to analysis of variance or regression analysis. Inverse regression analyses within replicates of each cultivar were used to predict yield decrements. Means between cultivars were then separated using Waller-Duncan k-ratio $t$ test with $\mathrm{k}=100$.

No interactions of cultivar $\times \mathrm{EC}$ were found for leaf water potential components (Table 1). Therefore, data points in Fig. 1 were based on means averaged over four cultivars. Average leaf water potential $(b=-0.045)$ declined more rapidly than osmotic potential $(b=-0.037)$ as salinity increased in the root zone (Fig. 1). This difference is reflected in declining average turgor potentials, which decreased linearly as salinity increased to values $<0.1 \mathrm{MPa}$ at the highest salt level. Nevertheless, positive turgor was maintained at a salt level $\left(41.5 \mathrm{dS} \cdot \mathrm{m}^{-1}\right)$ equal to seawater.

Interactions of cultivar $\times \mathrm{EC}$ were observed for top and root growth but not for crown growth (Table 1). When averaged over all cultivars, growth of crown tissue responded quadratically to increased salinity, with

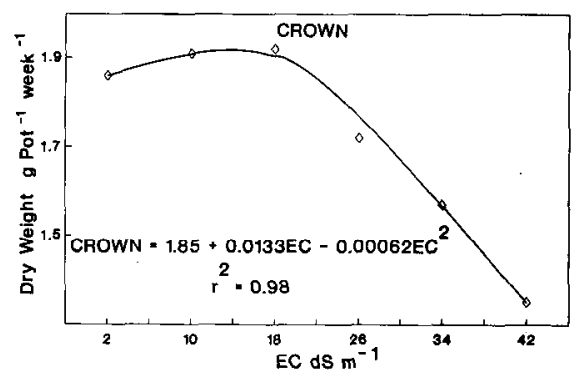

Fig. 2. Composite crown growth response of St Augustinegrass cultivars to salinity. Each data point represents the mean of 20 observations.

Table 2. Electrical conductivity $\left(\mathrm{dS} \cdot \mathrm{m}^{-1}\right)$ of the solution culture to effect top growth reductions as predicted by inverse regression analyses and root growth rate slopes (b) of St. Augustinegrass cultivars.

\begin{tabular}{lcrrrrr}
\hline & \multicolumn{7}{c}{ Top reduction (\%) } & \\
\cline { 2 - 7 } Cultivar & 5 & 10 & 15 & 25 & 50 & Root \\
\hline Seville & $6.6 \mathrm{a}^{\mathrm{z}}$ & $10.1 \mathrm{a}$ & $12.9 \mathrm{a}$ & $17.8 \mathrm{a}$ & $28.1 \mathrm{a}$ & $-2.73 \mathrm{a}$ \\
Floratine & $3.3 \mathrm{~b}$ & $5.5 \mathrm{~b}$ & $7.6 \mathrm{~b}$ & $12.0 \mathrm{~b}$ & $22.9 \mathrm{~b}$ & $-4.66 \mathrm{~b}$ \\
Floratam & $3.2 \mathrm{~b}$ & $5.4 \mathrm{~b}$ & $7.5 \mathrm{~b}$ & $11.8 \mathrm{~b}$ & $22.9 \mathrm{~b}$ & $-5.41 \mathrm{bc}$ \\
Floralawn & $3.2 \mathrm{~b}$ & $5.3 \mathrm{~b}$ & $7.4 \mathrm{~b}$ & $11.7 \mathrm{~b}$ & $22.6 \mathrm{~b}$ & $-6.08 \mathrm{c}$
\end{tabular}

${ }^{2}$ Mean separation within columns at $P=0.05$ using Waller-Duncan k-ratio $t$ test.
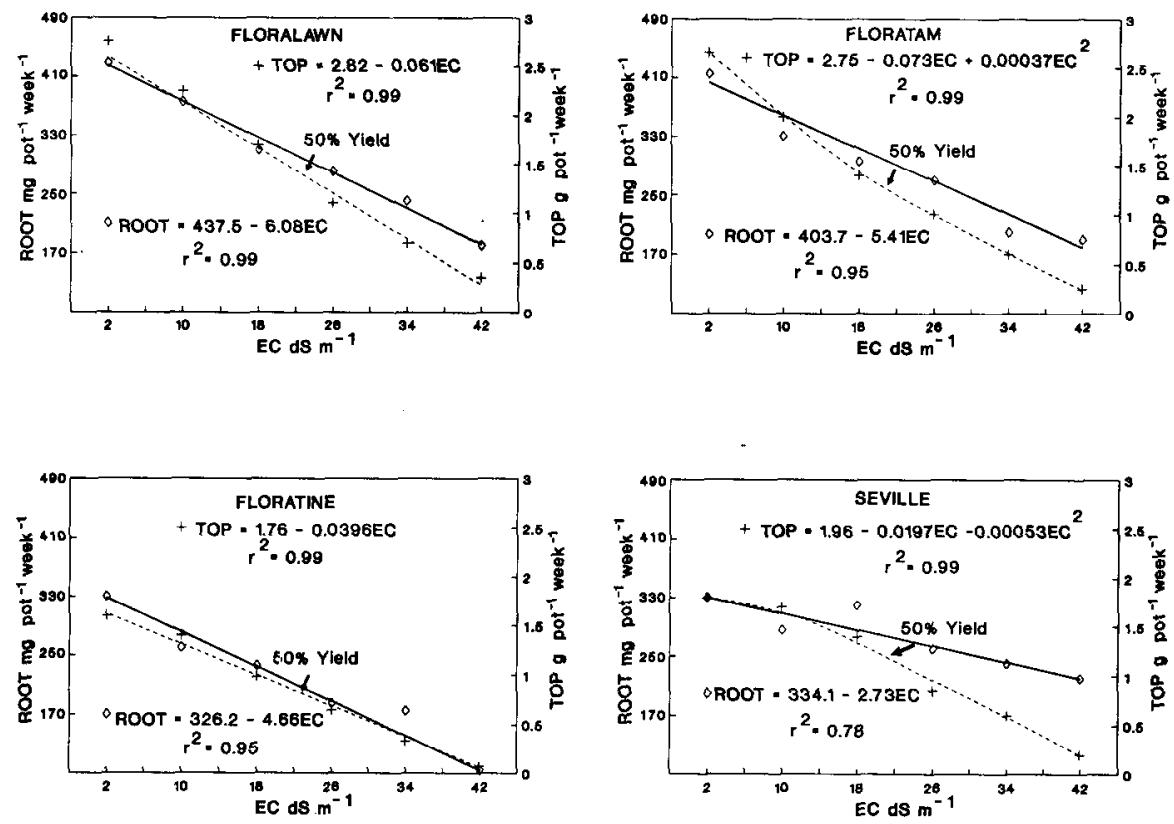

Fig. 3. Influence of salinity on top and root growth rate of St. Augustinegrass cultivars. Each data point represents the mean of five observations.

maximum growth at $10.7 \mathrm{dS} \cdot \mathrm{m}^{-1}$ (Fig. 2). This result was an $8 \%$ increase in growth over that in nonsalinized solutions. Top growth declined linearly with increased salinity for 'Floratine' and 'Floralawn', while that of 'Floratam' and 'Seville' declined quadratically (Fig. 3). 'Seville' was superior to other cultivars at all measured top growth decrements (Table 2). It had a $50 \%$ yield reduction at $28.1 \mathrm{dS} \cdot \mathrm{m}^{-1}$, while other cultivars had $50 \%$ yield reductions at 22.6 to $22.9 \mathrm{dS} \cdot \mathrm{m}^{-1}$. Surprisingly, 'Seville' St. Augustinegrass had salt tolerance equal to 'FSP-1' Seashore paspalumgrass (Paspalum vaginatum Swartz.) (Dudeck and Peacock, 1985) and to several bermudagrass (Cynodon spp.) cultivars (Dudeck et al., 1983). Differences in salt tolerance between cultivars were greatest at low salt levels (Table 2). At topgrowth reductions $<10 \%$, salt tolerance of 'Seville' was double that of other cultivars. We found this same relationship in Seashore paspalumgrass, in that cultivar differences were greatest at salinity levels $<15 \mathrm{dS} \cdot \mathrm{m}^{-1}$ (Dudeck and Peacock, 1985). This characteristic of 'Seville' is especially important to forage or turfgrass managers because subtle differences in plant density or growth rate would not be. readily apparent when irrigating with saline water. No differences in top growth were found between 'Floratine', 'Floratam', and 'Floralawn' because of salinity. Salinity had less effect on root than on top growth (Fig. 3).
Root growth reduction in 'Seville' was least affected by salinity (Table 2), in that it showed the least reduction in root growth rate with increased salinity $(b=-2.73)$. Root growth in 'Floratine' and 'Floratam' was reduced about twice as much $(b=-4.66$ and -5.41 , respectively), although 'Floralawn' $(b=-6.08)$ was not different from the latter cultivar.

None of the cultivars died, although top growth was severely reduced at the highest salt level $\left(41.5 \mathrm{dS} \cdot \mathrm{m}^{-1}\right)$. Growth of crown tissue was least affected, while root growth was intermediate. 'Seville' St. Augustinegrass was the most salt-tolerant cultivar, being superior to other cultivars, especially at low salt levels.

\section{Literature Cited}

Beard, J.B. 1973. Turfgrass science and culture. Prentice-Hall, Englewood Cliffs, N.J.

Dudeck, A.E. and C.H. Peacock. 1985. Effects of salinity on Seashore paspalum turfgrasses. Agron. J. 77:47-50.

Dudeck, A.E., S. Singh, C.E. Giordano, T.A. Nell, and D.B. McConnell. 1983. Effects of sodium chloride on Cynodon turfgrasses. Agron. J. 75:927-930.

Harivandi, M.A., J.D. Butler, and D.M. Soltanpour. 1982. Salt influence on germination and seedling survival of six cool-season turfgrass species. Commun. Soil Sci. Plant Anal. 13(7):519-529.

Hoagland, D.R. and D.I. Arnon. 1950. The water-culture method for growing plants without soil. Calif. Agr. Expt. Sta. Circ. 347. 
Hoos, D.D. 1981. Salt injury-An increasing problem. U.S. Golf Assn. Green Sect. Rec. 19:1-3.

Horst, G.L. and N.B. Beadle. 1984. Salinity affects germination and growth of tall fescue cultivars. J. Amer. Soc. Hort. Sci. 109(3):419-422.

Horst. G.L. and R.M. Taylor. 1983. Germination and initial growth of Kentucky bluegrass in soluble salts. Agron. J. 75(4):679-681.

Levitt, J. 1980. Responses of plants to environmental stresses. vol. II. Academic, New York.
Lunt, O.R., V.B. Youngner, and J.J. Oertli. 1961. Salinity tolerance of five turfgrass varieties. Agron. J. 54(4):247-249.

Parker, G.G. 1975. The hydrogeology and problems of peninsular Florida's water resources. Proc. Fla. Turfgrass Mgt. Conf. 23:13-36.

Peacock, C.H. and A.E. Dudeck. 1984. Physiological response of St. Augustinegrass to irrigation scheduling. Agron. J. 76:275-279.

Peacock, C.H. and A.E. Dudeck. 1985. Physiologi- cal and growth responses of Seashore paspalum to salinity. HortScience 20(1):111-112.

Svedrup, H.V., M.W. Johnson, and R.H. Fleming. 1959. The oceans, their physics, chemistry, and general biology. Prentice Hall, Englewood Cliffs, N.J.

Youngner, V.B., O.R. Lunt, and F. Nudge. 1967. Salinity tolerance of seven varieties of creeping bentgrass, Agrostis palustris Huds. Agron. J. 59(4):335-336. 